Article

\title{
The Hauntings of Canada in Michael Crummey's Sweetland
}

Vanja Polić ${ }^{1, *}$

How to cite: Polić, V. 'The Hauntings of Canada in Michael Crummey's Sweetland.' London Journal of Canadian Studies, 2018, 33(1), pp. 77-93. DOI: https://doi.org /10. 14324/111.444.ljcs.2018v33.006.

Published: 14 November 2018

\section{Peer Review:}

This article has been peer reviewed through the journal's standard double-blind peer-review, where both the reviewers and authors are anonymized during review.

\section{Copyright:}

(c) 2018, The Author(s). This is an Open Access article distributed under the terms of the Creative Commons Attribution License (CC-BY) 4.0 https://creativecommons.org/licenses/by/4.0/, which permits unrestricted use, distribution and reproduction in any medium, provided the original author and source are credited $\bullet$ DOI: https://doi.org/10.14324/111.444.ljcs.2018v33.006.

\section{Open Access:}

London Journal of Canadian Studies is a peer-reviewed open access journal.

\footnotetext{
*Correspondence: vpolic@ffzg.hr

${ }^{1}$ University of Zagreb, Croatia
} 


\title{
The Hauntings of Canada in Michael Crummey's sweetland
}

\author{
Vanja Polić
}

\begin{abstract}
In Michael Crummey's novel Sweetland (2014), which belongs to the genre of Canadian Gothic, ghosts function as warnings and reminders on a broader cultural and national level. The article analyzes different kinds of hauntings in the novel to show how they emphasize the notions of belonging to a local community and specific location, to alert to the disappearance of the traditional ways of life and the importance of cultural memory for the survival of a comprehensive and diversified Canadian identity. The hauntings include: 'typical' ghosts haunting individual characters; workings of capital and national consolidation, which are shown haunting the local community (serving as a synecdoche of the Newfoundland region); hauntings of disappeared local communities in the impersonal national construct of Canadian culture (cultural mosaic); hauntings which emphasize notions of belonging to and emplacement into Canada's Atlantic region; the haunting of the unrecordable quality of lived experience in such a community; and the inevitability of the book to be a record of absence as well as warning of that absence. The article discusses and postulates hauntings as a strategy of resistance against historical amnesia, but also as testaments to belonging.
\end{abstract}

Keywords: Michael Crummey, Sweetland, Canadian Gothic, haunting, ghosts, belonging, cultural haunting, historical erasure, storied pasts, capital 
Michael Crummey's novel Sweetland (2014) is teeming with ghosts and haunting. Unlike popular versions of ghost stories, which portray ghosts haunting individuals to cause them psychological and physical distress, Crummey's ghosts function as warnings and reminders on a broader cultural and national level. This article will analyze different kinds of hauntings in the novel to show how they serve to emphasize the notions of belonging to a local community and specific location in order to alert readers to the disappearance of the traditional ways of life and the importance of cultural memory for the survival of a comprehensive and diversified Canadian identity. Sweetland revolves around a small island community off the southern coast of Newfoundland that has supported itself with fishing for over two hundred years. Fishing was one of the first reasons for the European interest in what is today known as the Atlantic region of Canada, its subsequent settlement and, in the twenty-first century, its stagnation. Within Canada, the region's outports served their economic purpose as an internal colony ${ }^{1}$ until the depletion of the salt fish resources, marked by the cod fishing moratorium in 1992. Crummey's novel traces the aftermath of the moratorium, historicizing the political and economic reasons for the region's flailing status within Canada, and juxtaposing the often a-human workings of capital to the local human history and culture. By situating the novel geographically and economically in the 'ex-centric'2 part of Canada, Crummey engages in the dialogue of the centre and the margin; offering 'a more sophisticated understanding of the ambivalence of the storied pasts of both the Maritimes and Newfoundland, and a more sophisticated understanding of the economic, political, and cultural dynamics that shape the region's tenuous position within the present neo-liberal order'. ${ }^{3}$ Crummey shows that, instead of regarding the concepts of global and local as a binary, where the global is seen as distant and the local as present and 'here', the capital and global forces are 'very closely mapped onto the local', ${ }^{4}$ affecting the everyday existence and survival of local communities. Just as the ex-centre cannot operate without the centre as its point of reference, so the local is ineluctably interlinked with the global.

In Sweetland, the central storyline follows the village community on the island of Sweetland, which has been declining since the fishing moratorium and which has, in 2012, been offered a resettlement package by the government - one in a line of resettlement initiatives from 1949 onwards, aiming to effectively shut down the island and cut the costs of providing it with infrastructure. In the novel, all but one of the island residents accept the package: the exception is Moses Sweetland, the novel's protagonist and focalizer, and for the large part of the novel, the island's 
only living inhabitant. His memories constitute an array of local histories of the island and islanders which intersect the novel's story-now, revealing a present haunted by the past. Moses is also one of the two characters in the novel who sees ghosts and feels their presence. The other character is his grandnephew, Jesse, described by Moses as an 'idiot savant ${ }^{5}$ boy who insists that Moses's dead brother Hollis is his best friend. Unlike Moses, who feels uncanny in the presence of ghosts, to Jesse they are as 'real' as any other living resident on the island. Jesse's equanimity and matter-of-fact acceptance of ghosts underlines his sense of belonging to the island.

In fact, it seems that ghosts of different kinds permeate this novel from its vey opening lines in which Moses, returning from the Newfoundland mainland with a boat-load of wood, comes across Sri Lankan refugees illegally trafficked to North America and abandoned to drift at sea in a rescue boat. The scene is set in Gothic fashion: as Moses travels in thick fog, he hears voices 'so indistinct he thought they might be imaginary. An auditory hallucination, the mind trying to compensate for a sensory lack. The way a solitary man will start talking to furniture, left alone long enough. ${ }^{6} \mathrm{He}$ hears 'a murmur that seemed vaguely human . . . a single wordless syllable shouted, like a dog's bark. Spooked him. Miles out on the water and that voice seeming to rise from the ocean itself. ${ }^{7}$ When he finds the courage to respond, 'hoping there was nothing in that blankness to answer him, ${ }^{8}$ and hears dozens of voices shouting wildly, he feels as if an invisible hand has protruded from the fog and pushed him. Then he sees '[a] shape slowly taking shape in front of him' and as he tugs the refugees to the island, each time he looks back he is 'startled ... to see what was following in his wake. ${ }^{9}$ This opening scene introduces two themes that intertwine throughout the novel: the question of displacement, of refugees and exiles who have lost their community and home, and consequently have to relocate to an unknown destination, and the genre of the Gothic to describe this state. These refugees, who are sheltered briefly on the island of Sweetland before taken over by the Coast Guard, serve as harbingers of the destiny that awaits all the island's residents, since they themselves will become internal exiles scattered throughout continental Canada, rootless and without real connections to that other place to which they will relocate. The Sri Lankans also symbolize a threshold, a liminal space of the end of an era where the traditional way of life no longer exists and the future is uncertain and cannot be espied.

The Gothic description of the refugees as ghosts very strongly evokes Cynthia Sugars's and Gerry Turcotte's concept of the postcolonial Gothic, as well as Marlene Goldman's notion of (dis)possession. Sugars 
and Turcotte develop the concept in relation to the "unhomely" or "spectral" legacies of imperialism and globalization' 10 which in literature take "the form of ghosts or monsters that "haunt" the nation/subject from without and within..11 And while Sugars and Turcotte primarily link the concept of the Gothic to the postcolonial, their arguments can be fittingly applied to Crummey's novel because they translate to the Canadian workings of capitalism, imperialism and national consolidation within its own nation-state. The Canadian state is, so to speak, trimming its edges in order to lower the costs of the colony's maintenance, and it is these 'assimilative dynamics of . . . nationalism which give rise to the Gothic'. ${ }^{12}$ The Gothic as a genre, in its turn, 'is preoccupied with the fringes, the unspoken, the peripheral, and the cast aside. It is populated with monsters and outcasts, villains and victims, specters and the living dead. ${ }^{13}$ The Sri Lankan refugees adrift at sea symbolize 'the transnational spectral tropes identified with free-floating capital' which 'exceed the border of the nation-state', ${ }^{14}$ mirroring the movements of capital and globalization within Canada, where the island residents will become internal exiles adrift in the spaces of Canada, all of them living ghosts, situated in the in-between space of the displaced, neither here nor there. It is therefore not surprising that the motif of death permeates the novel, since in itself death represents a threshold between the world of the living and the world of the dead. In the novel the motif of death reoccurs both literally and metaphorically; literally since several characters die rather than leave the island - Queenie Coffin, who has not left her house in more than 20 years, dying of a heart attack instead of crossing the threshold of both her house and the island, and Moses's grandnephew, Jesse, dying in an accident after he is told he would have to relocate. The characters' existences are shown as inseparable from the locale, demonstrating Margaret Conrad and James Hiller's observation that the sense of community in the Newfoundland region is marked by 'a deep sense of place that sets Atlantic Canadians apart from many other North Americans'. ${ }^{15}$ On a metaphorical level, therefore, the dislocation of islanders from their storied space signifies the death of communal memory and ancestral inheritance.

Ghosts, and the Canadian Gothic ${ }^{16}$ as a specific genre, therefore signal a loss, but at the same time, as Sugars argues, can operate as 'a form of cultural sustenance and ... contestation'17 since Canadian Gothic authors engage in a dialogue with history in a twofold manner, by trying to trace where one belongs within history, and by investigating how one writes oneself into history (or, as historicity and historicization, respectively)..$^{18}$ Gothic tropes can perform a strategy of resistance against 
the historical oblivion and obsolescence; they 'initiate forms of cultural mourning (signalling a loss of cultural memory/history resulting from colonialism or migration)' 19 but nonetheless drawing attention to that act of disappearance or erasure. They are 'used to convey the way in which the Canadian national project is inherently haunted', ${ }^{20}$ and in Sweetland the islanders will remain as haunting presences that challenge and subvert the project/construct of Canadian national identity. Death is a silencing, and both the Sri Lankan and the island exiles are shown as disempowered, haunted by the workings of capital interests. However, as Margaret Atwood claims, ghosts 'want to talk, and they want us to sit down beside them and hear their sad stories'. ${ }^{21}$ The ghosts 'don't want to be voiceless; they don't want to be pushed aside, obliterated. They want us to know', 22 and it is from there that the doubleness of the Gothic discourse can be said to emerge. Ghosts guarantee a presence, an inscription into the landscape which reflects a long-standing desire of Canadian writing to write itself into the place and in this way 'lay claim to a Canadian genius loci or spirit of the nation'. ${ }^{23}$ By creating a traditional community which generates among its members 'trust and feelings of belonging' because it operates 'on a local scale that often assumed face-to-face contact', ${ }^{24}$ Crummey challenges the stereotype of Canada's pastlessness as a 'new' country in the New World at the same time as he challenges the overarching construct of national identity as a homogenizing (globalizing) ideology. In this sense Goldman's notion of (dis)possession can be used to describe one of the crucial issues that the novel foregrounds. Goldman defines (dis)possession as the suture of 'the fiction's manifest content of spirit possession to the more shadowy, traumatic, and latent experience of dispossession instigated by clashes between cultures' 25 of marginalized groups 'whose knowledges have been elided and, at times, forcibly repressed by the . . Canadian nation-state'. ${ }^{26}$ The dismantling of the island community, which serves as a synecdoche for the Newfoundland region and its position within the Canadian national project, transforms the Canadian genius loci into 'haunted loci'. ${ }^{27}$ The hauntings of capital, political and financial interests that have brought the community into existence will now be the agents of its dismantlement.

However, next to these capital forces which produced a colony, Crummey posits the people who have created the colonial community. These people have imprinted themselves onto the space, primarily through stories and naming. The novel's protagonist, Moses Sweetland, is a reticent and bullheadedly diffident man, ${ }^{28}$ but he is also the 'unofficial custodian of the cemetery' 29 and the island's story-keeper, the focal point in which the past and the present meet. This connection between the past 
and the present, the people and the locale, the stories and space is most obvious in the island's toponymy: the island sites have names of local significance, places like Vatcher's Meadow or Lunin's Rock, where names were given after a person. Others are quite prosaic, ordinary: King's Seat, Mackerel Cliffs, Devil's Under-jaw, Murdering Hole, Old Chimney, Mad Goat Gulch - all toponyms evocative of the early settlers naming the landscape around them to counter the acute feeling of displacement in a new space. The naming of surroundings signifies emplacement, appropriation and, ultimately, settlement into the space. The very name of the island is eponymous with the protagonist, further strengthening the connection between a person and 'his' place. Moreover, when Moses Sweetland remains alone on the island, after all the residents have relocated to other parts of Canada, he recreates in his mind the map of the island, 'careful to include as much detail as possible, as though the island was slowly fading from the world and only his ritual naming of each nook and cranny kept it from disappearing altogether'. ${ }^{30}$ It is through this 'ritual naming' that he maintains and reaffirms his storied connection to the island. However, Moses's fear of the island disappearing is not entirely unfounded, because the island does not, in a manner of speaking, fully exist in the first place: the geographical map of the Newfoundland archipelago that Moses comes across soon after his ritual naming only outlines the island of Sweetland, but does not name it. The contrast between the place to which he belongs and where he has chosen to remain against all odds, versus the impersonal drawing on an official map is described as 'the irregular yellow oblong [of Sweetland] where he had spent almost his entire existence'. ${ }^{31}$ What is more, Moses also spends 'a better part of the hour . . . adding missing names along the coastline, drawing in small islands that had been inexplicably left out' 32 from the official map. Moses's subjective narration in the sentence is worth noting, because all the small islands are, in his opinion, 'inexplicably' omitted, whereas they are probably too small (and/or irrelevant) to be included on the map of the Newfoundland archipelago issued by the government. Another discrepancy is shown in this impersonal map which is, nonetheless, titled Come Home Year. ${ }^{33}$ Moses crosses out the title and writes 'Stay Home Year' instead. The incongruity between the official mapping of the space and Moses's 'reading' of his landscape reiterates the notion of the spectres of the local as haunting the national project. Moses writes the island's name on the map, but that act does not seem to satisfy him, so he continues to re-name other locations on the southern shore of Newfoundland, all after the people he has known, such as Jesse's Head, Priddle's Point and Queenie's Island. ${ }^{34}$ In the same way in which the early explorers wanted to leave their trace of having been 
there, of leaving their mark for posterity, so does Moses inscribe and emplot the landscape, appropriating it and making sure that some trace of his community is left on it. By imprinting the names of his familiars into the map's landscape and strengthening the connection between the space and the histories that people have traced on it, Moses reveals that he is haunted by the people who have left the island in equal measure in which he is haunted by the people close to him who have died. The trope of haunting here underlines the symbolic traces of individual and communal histories functioning as palimpsests to the larger workings of the Canadian national project. 35

But Moses is not only the haunted one, he is also the haunter. During his residence alone on the island, he exists in the in-between space of the island's future in which there is no longer a colony of people on the island, and the peopled past which he cannot bring back. He is now haunting the island, and he has used the threshold of death to achieve that: after his grandnephew Jesse's accidental death, Moses fakes his own in order to stay on the island. He links his own death to the death of the island, but at the same time remains on the island, continuing in his way of life which has for everyone else ceased to exist (perhaps in this way presaging that it is only through actual death that he will be able to remain permanently on the island). Thus Moses finds himself on the threshold, and even though he has occasionally felt the presence of ghosts even while the other islanders were still on the island, he has refused to fully accept them, shaking them away as uncanny feelings. He was sceptical of Jesse's claims to communication with Moses's dead brother, Hollis, or of Jesse's insistence on seeing the light in the window of the house of recently deceased Queenie Coffin. However, as Moses remains alone on the island, he himself starts experiencing the presence of ghosts. Not only does he start to see the light in Queenie's window, he also, through that window, notices two simultaneous manifestations of Queenie holding hands - one as a young girl and one as an old woman - who, though not acknowledging him directly, do appear to him. Other ghostly instances include Moses lost at sea in thick fog and hearing music from the bell tower, which guides him safely back to the shore, and ghostly rifle shots fired in celebration of the New Year's Eve. But a central event takes place as Moses walks near the cliffs late one night. Again the scene is described in typical Gothic fashion for, as he walks towards the cliffs, Moses can 'see the light over the rise, an intermittent glim like photographs being taken, away in the distance . . . a calm that felt otherworldly had settled on the night'. ${ }^{36}$ Then he sees 'the first of them moving on the rise. Dark figures outlined in flashes against the horizon, heading toward the lighthouse.' ${ }^{37}$ Moses Sweetland 
stands motionless, watching as the silhouettes pass by one after the other, following the same path. He considers turning away but the was afraid to look away, thinking [the ghosts] might disappear if he did. He watched the silent procession swell above him. ${ }^{38}$ As the last of the figures pass, he follows them 'moving slow in the unearthly quiet'. ${ }^{39}$ As he comes close to the lighthouse he sees

hundreds of them standing on the headlands. All clustered close to the cliffs of the Fever Rocks, as many people as ever lived in the cove, he guessed, and not a sound among them. All facing the ocean where the intermittent light stirred the blackness. A pale glow about the unlikely congregation though the moon was down, each figure silhouetted against the night sky. An air of waiting about them so palpable that Sweetland held his breath as he watched. ${ }^{40}$

He feels as if he is spying on a secret ceremony and turns to sneak away when a vaguely familiar form brushes past him, causing him to clutch firmly at his gun with both hands 'to fend off the night'. ${ }^{41}$ The procession continues to walk 'down from the rise in a steady trickle . . . their faces blank and unhurried'. ${ }^{42}$ Most importantly, they seem to accept him even though he is on the other side of the life-death threshold because '[t]hey went past [him] without showing the slightest concern to have him there. Strangers every one of them, though he felt they knew him. That he was known to them somehow. ${ }^{43}$ And what is more, one of them turns her head towards him as she walks by and smiles at him blankly. He recognizes her as his sweetheart from his younger days. The feeling of recognition and acceptance by the ghosts, though elusive, stays with Moses as he later remembers seeing the 'crowd assemble there in their echoing cathedral silence'. ${ }^{44} \mathrm{He}$ tries to rationalize the apparitions as '[a] lunatic's vision', but is at the same time comforted by the fact that 'something about it seemed beyond his capacity for fabrication, even drunk as he was'. 45 Moreover, the feeling of at-homeness settles over him because he has a 'sense that he'd known them in another lifetime', ${ }^{46}$ even if he cannot clearly recall either their names or their faces.

All three instances of Moses's contact with the ghostly emphasize their presence on the island and Moses's gradual 'initiation' into their world, on the other side of the threshold. Interestingly, these encounters show that it is not they who need to accept him, because apparently they already do, but it is Moses who needs to become accustomed to their presence. What is more, it seems that they have led their existence on the island parallel to the world of the living, and Moses, who has previously 
only had an uncanny feeling that testified to their existence, now receives enough evidence of their company. He finds himself increasingly longing for the latter, as their presence assuages his extreme loneliness on the island, loneliness which reflects his status as the last of his kind. Moses's feeling of familiarity with the ghosts can be further explained in terms of 'settled unsettlement', ${ }^{47}$ which Sugars defines as 'the sensation of haunting' that 'bolster[s] a sense of belonging' ${ }^{48}$ where haunting no longer functions as a threat but as a reaffirmation of emplacement. Moses at this later stage of the novel longs for the uncanniness of haunting because it functions as cultural infusion or, in Moses's case, as a sense that he belongs to the island community. ${ }^{49}$ However, his belonging is at this stage in the novel also undergoing a transformation because the living community no longer exists, but he, as a living being, at present still remains on one side of the threshold, in the land of the living, glimpsing across it at the spectral world of the dead.

At the same time, the place which he inhabits is undergoing an uncanny slippage of its own. The gradual transition from the locale of the living to the liminal space of the threshold, and from there to the space of the dead, is well exemplified by the growing discrepancy between the weather forecasts from the $\mathrm{CBC}$ radio station and the weather that Moses experiences on the island. He experiences the first inconsistency around New Year when the snow sets in on the island even though the radio predicts 'clear skies and milder than normal temperatures along the south coast'. ${ }^{50}$ After that the weather on the island turns 'to its regular schizophrenia'51 but the forecast is consistent about the mildness of weather conditions. Moses gradually changes his attitude towards this discrepancy: 'It had been comic at first, to see the forecast so far off the mark day after day. But there was something increasingly disturbing in the disconnect. It seemed a sign of a widening fracture in the world. ${ }^{52}$ And in this widening fracture, the island gradually transforms into an in-between space, a heterotopia, a counter-site, 'a kind of effectively enacted utopia in which the real sites, all the other real sites that can be found within the culture, are simultaneously represented, contested, and inverted'. 53 The island, due to the disconnect with the 'real' world represented by the radio forecasts, starts to drift away from the 'reality-level' of the novel, and as such starts resembling a boat, like the free-floating rescue boat with the Sri Lankans from the opening scene from the novel.

This metamorphosis of the island into a boat turns the boat-island into 'a floating piece of space, a place without a place, that exists by itself, that is closed in on itself and at the same time is given over to the infinity of the sea'. ${ }^{54}$ The island that is functioning independently of the world 
around it, in other words, becomes an example of heterotopia, a countersite to the project of Canadian national identity, its counter-history and a haunting reminder of the importance of cultural memory. As such, it lays bare the notion of 'Canadian culture as a consciously constructed "culture of memory" 55 and designates 'the tentativeness of the Canadian project since its foundations', ${ }^{56}$ emphasizing the contesting sites of production of cultures, knowledges and histories which tend to be subsumed within the national project of the Canadian cultural mosaic. The island, consequently, functions as a site of counter-history, pointing towards 'those experiences and memories that have not been heard and integrated in official histories, ${ }^{57}$ but through the use of Gothic discourse they 'mediate forgotten histories' 58 and 'signal an attempt to recover and make use of poorly documented, partially erased cultural history'. ${ }^{59}$ The island's Gothic slippage into the threshold of heterotopia can be said to perform a strategy of resistance against the historical oblivion of the disappearing and disappeared world of the Newfoundland region of which the island and Moses (who is experiencing his own slippages) serve as a synecdoche and a metonymy respectively. It is important to note Michel Foucault's notion of counter-history here, which José Medina elaborates on when he claims that the production of counter-histories is 'possible because there are people who remember against the grain, people whose memories do not fit the historical narratives available. Counter-histories feed off such counter-memories and at the same time transform them, revitalizing practices of counter-memory and offering them new discursive resources to draw on. ${ }^{60}$ The Gothic ambiguity is obvious here, as the island's transformation into heterotopia and Moses's frequent encounters with ghosts reaffirm a sense of emplacement, the presence and richness of local cultural memory that morphs itself into the cultural memory of haunting.

As the novel draws to a close, another relevant Gothic episode unfolds, its finale building gradually. Having barely survived the winter on the island, Moses, sick and half-starved, dies at Easter, but this is not the end of the novel. Having died, Moses wakes up, sensing the total quiet of his house: the stove is cold but the light in the kerosene lamp is on. Moses sees the map he scribbled on spread across the kitchen table, and follows his drawings and renamed sites along the southern coast of Newfoundland. But he also notices that "[a]long the entire length of Newfoundland's south coast were the words Here Be Monsters with a shaky emoticon happy face drawn beside it. His handwriting, though he couldn't for the life of him remember setting them there. ${ }^{61} \mathrm{He}$ traces the coastline where he inscribed the islanders' names but as he glances toward the location where the island of Sweetland should be, he is shocked to find it 
missing. 'He had to work up the nerve to look closer, bringing the lamp down across the map for the light. Where he expected to see Sweetland there was nothing but blue water.' 62 The name he had written over the island is gone, 'even the ink outlines the names had been printed over were missing from the map. As if he'd only imagined seeing them there. ${ }^{63}$ It appears that with Moses' death, the island itself stops existing in official history and on the official map. The historical erasure has occurred before his eyes, and Moses is aware that the absence of the island on the map is ' $[\mathrm{s}$ ]o insignificant it would go unnoticed by anyone not looking for it'. ${ }^{64}$ What remains in the island's place is the inscription 'Here Be Monsters' in the blank sea of the map. The inscription directly recalls the maps drawn by the early explorers to North America, which dotted the unmapped land with miniature drawings of fabulous monsters, and sections labelled with the same sentence, all evoking the explorers' early encounters with the unknown, undiscovered lands of the New World. In Sweetland, the reverse process occurs as the land that was known, inhabited, storied, and historied for centuries, disappears from the map by the end of the novel, replaced by the old phrase signalling a slipping into the world of the unknown. And while the early explorers imbued the 'empty' landscape with Gothic presence, ${ }^{65}$ the reverse process in Sweetland enacts a historical erasure.

Having burnt the map, Moses leaves the house and goes towards the headlands 'away from all he'd ever known or wanted or wished for'. As he looks behind him, there is 'nothing below but a featureless black, as if the ocean was rising behind him and had already swallowed the cove and everything in it'. ${ }^{66} \mathrm{He}$ is looking for the host of figures on the rise and when he sees them 'moving toward the light, all travelling at the same methodical pace, with the same lack of urgency', ${ }^{67}$ he falls in with them. The 'walkers so close he could feel the cold rising off their coats, a scoured smell in the air around them, linseed and raw salt and spruce. They didn't acknowledge Sweetland or show the slightest concern that he was there. ${ }^{68}$ He recognizes a woman in the group. At the same time ' $[\mathrm{h}]$ is companions looked to be numberless in the dark and strangers every one of them. But he was grateful for their presence just the same.' ${ }^{69}$ The figures are 'calm and all in silence, ${ }^{70}$ and Moses is uncertain whether he should follow them to the cliffs until he sees an apparition of a boy and he follows him instinctively. At the cliffs 'he lined along the headlands beside the others. A press of silent figures with their faces turned to the open sea. They seemed resigned and expectant standing there, their eyes on the fathomless black of the ocean. Sweetland anonymous among that congregation. He felt of a sudden like singing. ${ }^{71}$ The final ghost scene thus completes the circle initiated by the novel's ghostly opening. 
As the last living inhabitant of the island dies, the island is now entirely inhabited by monsters or, more precisely, ghosts. The inscription on the map turns out to be ironically accurate. The Gothic has encroached as the living people have disappeared. Cultural haunting ${ }^{72}$ has set in: the ghosts in the novel serve as agents of cultural memory because they are inscribed into the place and familiarize it, making it unsettlingly homey. The ghosts, who are unheimlich by the very definition of the Gothic genre, underline the paradox of the at-homeness of the island. However, Crummey subverts the concept of home, juxtaposing the notion of traditional and firmly emplaced community with the impersonal, depersonalizing, nationalizing and globalizing impulses which destabilize the traditional communities. Consequently, as Goldman notes, 'home as a constant has become less of a given, as more and more people are unhomed-often forced to exist in a kind of liminal space, traditionally associated with the ghost'. ${ }^{73}$ In Sweetland, the instability of home is symbolized not only by the Sri Lankan refugees or the resettled island residents, but also by Moses Sweetland himself, who turns into a ghost to find fulfilment in his chosen community. He is, after all, named Moses, but unlike his biblical predecessor, he can enter his promised land. Crummey's novel can therefore be said to start with the notion of unsettled settlement, for the haunting is executed by the government upon the community, and it ends with the settled unsettlement, where haunting reaffirms a sense of belonging and emplacement.

And while Moses has become a member of a community where he feels at home, at the end of the novel, he is left standing and gazing expectantly towards the horizon, perhaps only partly satisfied. The expectancy indicates that there is another threshold outside of the novel at the end of which no one is left alive. The novel itself represents an overlapping, as Moses shares his surname with the island, and both share the name with the novel. The novel's subject matter thus in a feat of trump l'oeil transcends its literary boundaries and poses questions about the future of the whole region and the loss of the lore, of people and individual lives which will go unrecorded but were lived and have contributed to the project of Canada. The novel asks how the project of Canadian national identity mitigates and negotiates these small chips of the mosaic. Crummey's novel can be said to emphasize that these local communities are the ones that make up the entirety of the Canadian cultural mosaic, contribute to its diversity, and should not be lost in the globalizing, nationalizing projects of Canada. The local, which is closely woven and influenced by the global, should not lose out. Moses becoming a ghost joins the Gothic in its emphasis of loss, but also of belonging, community, the threshold of expectancy about the 
future. To paraphrase Roland Barthes's well-known statement, culture is in the novel represented not as a large impersonal construct, but as a mosaic of quotations drawn from the innumerable centres of culture. ${ }^{74}$

There is another paradox connected to the novel with regard to the question of historicity and historicization, or, in other words, to the question of where one resides within history and how one inscribes one's self or one's community into it. For Crummey, the act of writing poses yet another obstacle or a threshold for, as Goldman claims, the novels of haunting 'often strategically introduce obstacles that arrest the impulse to cross barriers and merge self and other. ${ }^{75}$ Crummey's record of a Newfoundland community becomes a record of absence, because it records a community which cannot recognize itself in the very record of itself. Nonetheless, this record acts culturally, politically and socially because it draws attention to the act of disappearance of the fringe communities within the national project of Canada. Crummey, with regard to his previous novel Galore, self-consciously mentions how, in his attempt to capture the disappearing world of these communities, he is paradoxically putting the last nail in the coffin, because he is admitting that that world is gone. ${ }^{76}$ The obstacle that prevents the crossing of the threshold between the self and the other is represented by Queenie Coffin, an avid reader of Harlequin romances, who hates reading the novels situated in Newfoundland that her daughter assiduously sends her in an attempt to improve her reading habits, because they in no way resemble, let alone represent, the life lived on the island. The processed reality does not resemble the experienced reality, and as a result, the book becomes a simulacrum, a signifier without a referent, no matter how hard it attempts to record that life. Thus it can be claimed that Crummey's novel is haunted by the unrecordable past of such outports, as is Crummey himself haunted with this disappearing and disappeared world that he constantly returns to in his works. Crummey's book can, therefore, be described as a record of absence, but paradoxically also as 'writing [that] ... survives its own performance' 77 and as 'a process that leaves a trail, like a series of fossilised footprints', ${ }^{78}$ as Atwood argues in connection to the nature of writing which is the only mode of performance that preserves a voice, the essence of a story. Using his novel as a literature of the threshold, and a countersite of memory, cultural memory and cultural haunting, Crummey is trying to instigate 'a form of memorial recuperation', ${ }^{79}$ or salvation from oblivion of the disappeared and disappearing world of the traditional Newfoundland communities. In Sweetland, he teaches us that one should learn to live with ghosts, since they are a strategy of resistance against historical amnesia, but also testaments to belonging. 


\section{Notes}

1 This is in line with J.M.S. Careless's hinterland-metropolitan thesis, according to which Central Canada has adopted the British colonial model and applied it internally, the metropolis or the centre exploiting the periphery or hinterland. J.M.S. Careless, 'Frontierism, Metropolitanism, and Canadian History', in One West, Two Myths II: Essays on Comparison, eds. Carol Higham and Robert Thacker (Calgary: University of Calgary Press, 2006), 193-214.

2 Linda Hutcheon, A Poetics of Postmodernism (New York and London: Routledge, 1988).

3 Herb Wyile, Anne of Tim Horton's: Globalization and the Reshaping of Atlantic-Canadian Literature (Waterloo: Wilfrid Laurier University Press, 2011), 26-27.

4 Harcourt quoted in Diana Brydon and William D. Coleman, 'Globalization, Autonomy, and Community', in Renegotiating community: Interdisciplinary Perspectives, Global Contexts, eds. Diana Brydon and William D. Coleman (Vancouver and Toronto: University of British Columbia Press, 2008), 10.

5 Michael Crummey, Sweetland (New York and London: W. W. Norton \& Company, 2015), 16.

6 Crummey, Sweetland, 3.

7 Crummey, Sweetland, 3.

8 Crummey, Sweetland, 3.

9 Crummey, Sweetland, 4.

10 Cynthia Sugars and Gerry Turcotte, 'Canadian Literature and the Postcolonial Gothic', in Unsettled Remains: Canadian Literature and the Postcolonial Gothic, eds. Cynthia Sugars and Gerry Turcotte (Waterloo: Wilfrid Laurier University Press, 2009), vii.

11 Sugars and Turcotte, 'Canadian Literature and the Postcolonial Gothic', vii.

12 Marlene Goldman, DisPossession: Haunting in Canadian Fiction (Montréal and Kingston: McGill-Queen's University Press, 2012), 13.

13 Sugars and Turcotte, 'Canadian Literature and the Postcolonial Gothic', xv.

14 Goldman, DisPossession, 12.

15 Margaret Conrad and James K. Hiller quoted in Wyile, Anne of Tim Horton's, 7.

16 Much has been written and theorized about the history and the present examples of the Canadian Gothic. For comprehensive studies, see for example Sugars (ed.), Unhomely States; Sugars, Canadian Gothic; Goldman, DisPossession; Edwards, Gothic Canada. In this article I will, therefore forego a historical survey of the tropes of Canadian Gothic such as Catherine Parr Traill, Susanna Moodie and Earle Birney, and focus instead on the analysis of the uses to which Crummey puts the Gothic in his novel Sweetland.

17 Cynthia Sugars, 'Phantom Nation', Zeitschrift für Kanada-Studien 31.2 (2011): 59.

18 Sugars, 'Phantom Nation', 60.

19 Sugars and Turcotte, 'Canadian Literature and the Postcolonial Gothic', xv.

20 Sugars and Turcotte, 'Canadian Literature and the Postcolonial Gothic', xv.

21 Margaret Atwood, 'Negotiating with the Dead', in On Writers and Writing (London: Virago, 2002), 146; italics in the original.

22 Atwood, 'Negotiating', 146.

23 Goldman, DisPossession, 5.

24 Diana Brydon and William D. Coleman, 'Globalization, Autonomy, and Community', in Renegotiating community: Interdisciplinary Perspectives, Global Contexts, eds. Diana Brydon and William D. Coleman (Vancouver and Toronto: University of British Columbia Press, 2008), 5.

Speaking of the emplacement of history, Crummey notices that:

in Newfoundland (I think this is more true in Newfoundland than anywhere else I have been in Canada) history is not schoolbooks. History is where your grandfather lived, what land your grandmother grew vegetables in, where people came from, where they had their summer places. It is still very physically present for people, and people have a real sense of ownership of the history of the place.

(Herb Wylie, Speaking in the Past Tense: Canadian Novelists on Writing Historical Fiction (Waterloo: Wilfrid Laurier University Press, 2007), 314.

25 Goldman, DisPossession, 20.

26 Goldman, DisPossession, 20-21. When discussing (dis)possession, Goldman always speaks of women, 
African-Canadian, indigenous and other marginalized groups, but her argument is valid for Crummey's novel because Sweetland depicts the imbalance of power between the centre and the margin by focusing on the repression of a local community for the larger interests of federal Canadian interest. That being said, due deference is paid to the differences in status and power/ disempowerment of various oppressed groups and the one described in Sweetland within the system of the Canadian nation-state.

27 Goldman, DisPossession, 32.

28 Crummey, Sweetland, 49.

29 Crummey, Sweetland, 203.

30 Crummey, Sweetland, 239.

31 Crummey, Sweetland, 247-248.

32 Crummey, Sweetland, 248.

33 Crummey, Sweetland, 248. 'Come Home Year-1966', Memorial University of Newfoundland, http://collections.mun.ca. The website explains the map's intention as '[a] welcome to relatives and friends returning to, and tourists visiting, the province in 1966', explaining that 'it was Joey Smallwood's idea to have a Come Home Year'.

34 Michael Crummey, Sweetland, 248.

35 I am paraphrasing Goldman, who speaks more broadly of the silencing of histories in colonialism. The argument, however, even though more general in its original context, is very applicable to the specific example of Crummey's novel. Goldman, DisPossession, 15.

36 Crummey, Sweetland, 263.

37 Crummey, Sweetland, 263.

38 Crummey, Sweetland, 263.

39 Crummey, Sweetland, 264.

40 Crummey, Sweetland, 264.

41 Crummey, Sweetland, 264.

42 Crummey, Sweetland, 264.

43 Crummey, Sweetland, 264.

44 Crummey, Sweetland, 264.

45 Crummey, Sweetland, 273.

46 Crummey, Sweetland, 273.

47 Sugars, 'Phantom Nation', 59.

48 Sugars, 'Phantom Nation', 59.

49 I am paraphrasing Sugars's broader discussion on the subject where she discusses the postcolonial Gothic's 'desire for the haunting effect of the uncanny as a form of cultural-historical infusion'. Cynthia Sugars, 'Phantom Nation', 66.

50 Crummey, Sweetland, 260.

51 Crummey, Sweetland, 269.

52 Crummey, Sweetland, 269.
53 Michel Foucault, 'Of Other Spaces', in The Visual Culture Reader, 2nd edn ed. Nicholas Mirzoeff, trans. Jay Miskowiec (London and New York: Routledge, [1998] 2002), 231.

54 Foucault, 'Of Other Spaces', 236.

55 Cynthia Sugars and Eleanor Ty, 'Thinking Beyond Nostalgia: Canadian Literature and Cultural Memory', in Canadian Culture and Cultural Memory, eds. Cynthia Sugars and Eleanor Ty (Don Mills: Oxford University Press, 2014), 5.

56 Sugars and Ty, 'Thinking Beyond Nostalgia', 6.

57 José Medina, 'Toward a Foucaultian Epistemology of Resistance: CounterMemory, Epistemic Friction, and Guerrilla Pluralism', Foucault Studies 12 (2011): 12.

58 Sugars and Turcotte, 'Canadian Literature and the Postcolonial Gothic', $\mathrm{x}-\mathrm{xi}$.

59 Again, Elizabeth Brogan and Goldman make the argument in relation to the African American narratives whose oppression is of a completely different scale than the one described in Crummey's novel because of the differences of race, histories of settlement, slavery, and present situation of inequality. However, as I will argue later, Crummey through his novel performs an act of resistance, describing the act of erasure from cultural memory of a marginal/ized community. Therefore, on a very general level, and with a lot of caution, and in a different context, I use Brogan's argument as an analogy. Elizabeth Brogan quoted in Goldman, DisPossession, 16.

60 José Medina, 'Toward a Foucaultian Epistemology of Resistance', 12.

61 Crummey, Sweetland, 316; emphasis in the original.

62 Crummey, Sweetland, 316-317.

63 Crummey, Sweetland, 316-317.

64 Crummey, Sweetland, 317.

65 Sugars, 'Phantom Nation', 60.

66 Crummey, Sweetland, 317.

67 Crummey, Sweetland, 318.

68 Crummey, Sweetland, 318.

69 Crummey, Sweetland, 318.

70 Crummey, Sweetland, 318.

71 Crummey, Sweetland, 318.

72 Elizabeth Brogan quoted in Goldman, DisPossession, 17.

73 Goldman, DisPossession, 14.

74 Roland Barthes, 'The Death of the Author', in Image Music Text, selected and 
trans. Stephen Heath (London:

HarperCollins, 1977), 146.

75 Goldman, DisPossession, 35.

76 Wylie, Speaking in the Past Tense, 297.

77 Atwood, 'Negotiating with the Dead', 142.

78 Atwood, 'Negotiating with the Dead', 142.
79 Sugars and Ty, 'Thinking Beyond Nostalgia', 9. Even though Sugars and Ty use the term more broadly for postcolonial historical fiction in Canada, it can be well applied in the case of Crummey's novel.

\section{Bibliography}

Atwood, Margaret. 'Negotiating with the Dead', in On Writers and Writing (London: Virago, 2002).

Barthes, Roland. 'The Death of the Author', in Image Music Text, selected and trans. Stephen Heath (London: HarperCollins, 1977).

Brydon, Diana and William D. Coleman. 'Globalization, Autonomy, and Community', in Renegotiating community: Interdisciplinary Perspectives, Global Contexts, eds. Diana Brydon and William D. Coleman (Vancouver and Toronto: University of British Columbia Press, 2008).

Careless, J. M. S. 'Frontierism, Metropolitanism, and Canadian History', in One West, Two Myths II: Essays on Comparison, eds. Carol Higham and Robert Thacker (Calgary: University of Calgary Press, 2006).

Crummey, Michael. Sweetland (New York and London: W. W. Norton \& Company, 2015).

Edwards, Justin D. Gothic Canada: Reading the Spectre of a National Literature (Edmonton: University of Alberta Press, 2005).

Foucault, Michel. 'Of Other Spaces', in The Visual Culture Reader, 2nd edn ed. Nicholas Mirzoeff, trans. Jay Miskowiec (London and New York: Routledge, [1998] 2002).

Goldman, Marlene. DisPossession: Haunting in Canadian Fiction (Montréal and Kingston: McGill-Queen's University Press, 2012).

Hutcheon, Linda. A Poetics of Postmodernism (New York and London: Routledge, 1988).
Medina, José. 'Toward a Foucaultian Epistemology of Resistance: Counter-Memory, Epistemic Friction, and Guerrilla Pluralism', Foucault Studies 12 (2011).

Sugars, Cynthia (ed.). Unhomely States: Theorizing English Canadian Postcolonialism (Peterborough, ON: Broadview Press, 2004).

Sugars, Cynthia. 'Phantom Nation', Zeitschrift für Kanada-Studien 31.2 (2011).

Sugars, Cynthia. Canadian Gothic: Literature, History and the Spectre of Self-Invention (Cardiff: University of Wales Press, 2013).

Sugars, Cynthia and Gerry Turcotte. 'Canadian Literature and the Postcolonial Gothic', in Unsettled Remains: Canadian Literature and the Postcolonial Gothic, eds. Cynthia Sugars and Gerry Turcotte (Waterloo: Wilfrid Laurier University Press, 2009).

Sugars, Cynthia and Eleanor Ty, 'Thinking Beyond Nostalgia: Canadian Literature and Cultural Memory', in Canadian Culture and Cultural Memory, eds. Cynthia Sugars and Eleanor Ty (Don Mills, ON: Oxford University Press, 2014).

Wylie, Herb. Speaking in the Past Tense: Canadian Novelists on Writing Historical Fiction (Waterloo: Wilfrid Laurier University Press, 2007).

Wyile, Herb. Anne of Tim Horton's: Globalization and the Reshaping of Atlantic-Canadian Literature (Waterloo: Wilfrid Laurier University Press, 2011).

\section{Notes on Contributor}

Vanja Polić is an assistant professor at the Department of English at the University of Zagreb, Croatia, where she teaches literary theory, 
contemporary Canadian literature and film, and the eighteenth century British novel. She has published articles on Canadian literature and culture in Croatian and international journals, and is the author of a monograph on the rhetorical practices of self-legitimation in the prefatory materials of the early eighteenth century British novel (2012). Her research interests include contemporary Canadian literature, postcolonial literature and postmodernism. Her current project concerns contemporary western Canadian literature, with special emphasis on the revisions of the myth of the West. She is the president of the Croatian-Canadian Academic Society and a member of the editorial board of Canadian Literature.

\section{Conflict of Interests}

The author declares that there are no conflicts of interests with this work. 